\title{
Integrating lucerne (Medicago sativa L.) into a high country merino system
}

\author{
D. ANDERSON ${ }^{1}$, L. ANDERSON ${ }^{1}$, D.J. MOOT ${ }^{2}$ and G.I. OGLE ${ }^{3}$ \\ ${ }^{1}$ Bog Roy, Private Bag 3, Kurow \\ ${ }^{2}$ Faculty of Agriculture and Life Sciences, PO Box 85084, Lincoln University 7647, Canterbury \\ ${ }^{3}$ Razare Systems, PO Box 9466, Hamilton 3240 \\ graeme.ogle@rezare.co.nz
}

\begin{abstract}
Farm systems in the dry sub-humid region of the Upper Waitaki predominantly graze merino ewes on extensive oversown and topdressed hill and high country. Smaller areas of flatter land are used to conserve winter forage crops, and grow supplementary feed and high quality pastures. The slow growth rate of merino lambs means they are traditionally retained on these improved pastures to finish in the following spring. In this system livestock demand peaks in the driest month of January and continues to be high through winter. Bog Roy is a farm that has changed this system and has established 200 ha of lucerne with the goal of fully feeding ewes during lactation. Pre-weaning lamb growth rate has increased from 205 to $235 \mathrm{~g} / \mathrm{head} /$ day, opening the opportunity to sell heavier lambs in early January. Ewe lamb replacements are reaching heavier pre-winter live weights (38 kg versus $35 \mathrm{~kg}$ ) and the flow-on effect is higher two-tooth scanning (129\% versus $111 \%)$ and weaning $(100 \%$ versus $84 \%)$. Lucerne has also improved the feeding of mixed age ewes from lambing to weaning, and lamb mortality has reduced from $30 \%$ to $21 \%$, increasing weaning from $115 \%$ to $130 \%$. The store production system also means livestock demand is kept low during the dry period and remains low through winter. Conserved feed is now only required for 50 days compared with 100 days in the traditional system. This has reduced supplementary feed costs from $\$ 10.33 /$ stock unit (SU) to $\$ 4.82 /$ SU. Shifting ewes to rotationally graze lucerne in large mobs early in the growing season has decreased the stocking rate on hill country. This has allowed cover to build during each spring with promising responses from legume species.
\end{abstract}

\section{Farm description}

\section{Contour, soils and vegetation}

Bog Roy is a 2860 ha station situated on the south eastern shore of Lake Benmore in the Upper Waitaki catchment of the South Island high country. The property starts at $400 \mathrm{~m}$ a.s.l. and rises to $1000 \mathrm{~m}$ a.s.l. It has a dry sub-humid climate with $380-400 \mathrm{~mm}$ of annual precipitation. Typical of high country stations, a large proportion is extensively farmed. Unimproved short tussock grassland running 0.3 stock units $(\mathrm{SU}) / \mathrm{ha}$ makes up $47 \%$ of the area, while a further $42 \%$ consists of oversown and topdressed hill country running 1.5 to $2.0 \mathrm{SU} / \mathrm{ha}$. The remaining $11 \%$ is now made up of 121 ha of predominantly flood irrigated pastures and 154 ha of lucerne and lucerne/cocksfoot pastures with 54 ha of this also flood irrigated. This flatter area is currently grazed by ewes with lambs at foot in spring, followed by weaned lambs. Prior to the increase in lucerne area there was 60 ha of dryland lucerne of which 30 ha was grazed and 30 ha conserved. The 100 ha of flood irrigated ryegrass based pastures were used each spring to finish the previous years lambs, which had been carried through the winter, before being closed up for baleage.

Soils are derived from loess deposited over thousands of years from the prevailing westerly wind. Flat land varies from shallow stony fluvio-glacial deposits through to deep loess. The low rainfall results in Pallic soils that are naturally high in $\mathrm{pH}$ and phosphorus but low in organic matter and sulphur. Pasture growth is influenced by (in order) altitude, aspect and soil depth. In spring, growth starts in mid-August on mid-altitude sunny hill country making it favourable for lambing ewes on the 20 September. Growth is normally reliable until mid-November when sunny aspects and shallower soils start drying off. Pasture growth on shady aspects and deeper soils continues for a further 3-4 weeks. By late December evapotranspiration rates are higher than rainfall and growth is expected to cease for at least 4-6 weeks. Evapotranspiration rates are lower in March and April, so autumn is important for growth which then ceases from early May through to mid-August due to cold temperatures.

\section{Stock}

The property runs an 18.0 micron merino flock with 3900 breeding ewes and 1700 ewe hoggets. Lambs are weaned in mid-January and all wether lambs are sold store. Ewe hoggets are kept through winter and 1000 are selected for replacements in mid-July. After shearing in mid-August, 500 of the cull ewe lambs are sold as replacement stock and 200 are sold to the works. From a Hereford beef herd of 110 cows and 20 in-calf heifers, all calves are sold at weaning in the first week of April with replacement heifers purchased in. 


\section{The motivation to change our system}

We took over ownership of Bog Roy in 2006. With the debt incurred we were intensely focussed on cashflow and profitability. Benchmarked against other merino properties, the business performed above average. This implied growing the business would not be straight forward. Also of concern was the decline in the condition of the oversown and topdressed hill country. Hieracium pilosella was increasing and clover, once abundant, was declining. Historically the oversown and topdressed hill was the platform for the lactating ewes from lambing to weaning.

At this time the renewal of a water consent for flood irrigation required conversion to spray irrigation and considerable capital expenditure. Initially this seemed an opportunity to grow the business by increasing the area irrigated and reduce our reliance on a variable summer. However, a detailed financial analysis showed the development might only generate sufficient added income to service the new borrowings. Beyond this, the only benefit was a gain in the capital value. To realise this value would require an exit strategy. The desire to continue rather than exit farming led to additional options being considered. This meant investigating whether per head performance of the animals could be improved via feed demand being more closely matched to feed supply, without compromising wool production.

The merino breed is characterised by a low lamb growth rate. This starts in utero with low lamb birth weight, a cause of high lamb mortality, and low postnatal growth leading to low weaning weights and finishing performance. Merino lambs are therefore not favoured by lamb finishers and are heavily discounted in dry years when lamb finishers prioritise heavy lambs that can be finished quickly. In contrast, the early spring market for lambs carried through winter is comparatively stable (Ogle 2009). Merino systems have adapted to this climate and market volatility by retaining the highest proportion of lambs possible within their feed supply to sell from October to December in the following year.

We experienced a very dry season in 2010 that reinforced that the business is dominated by the summer dry and a long winter. In spring our most productive stock class, lactating ewes, were set-stocked on hill country which was declining in productivity and forage quality. Finishing hoggets grazed the most productive land followed by a short period where this high quality feed was conserved to carry the current lamb crop through the next winter. Ewes came off hill country in acceptable condition but leaving very low covers. This system was chasing every blade of grass either to finish last year's lamb crop or conserve it for winter. The hill country supporting the lactating ewes seemed unsustainable and highly variable from one year to the next.

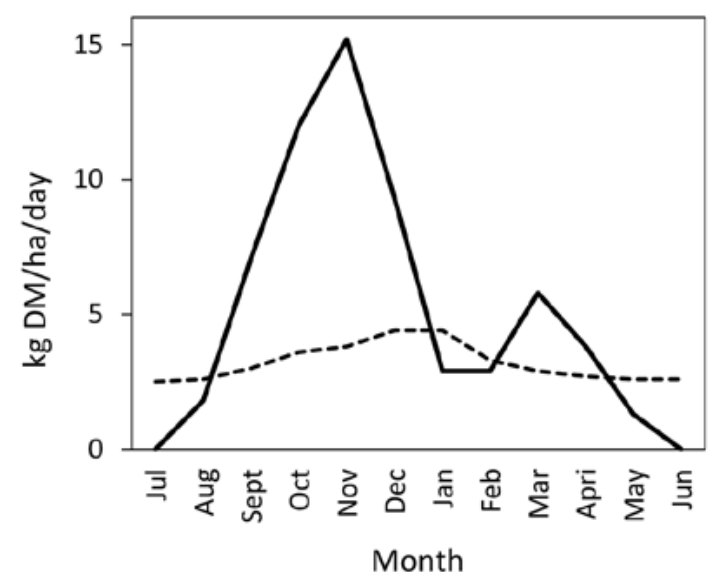

Figure 1 The feed supply (solid line) and feed demand (dashed line) calculated for Bog Roy Station using the Farmax modelling program.

\section{Analysing the system}

We started by focussing on what we could do to align our feed supply and demand. A model of our farm using the Farmax (Version 6.5.3.05) computer program (Marshall et al. 1991) demonstrated the misalignment with demand and supply (Figure 1). Pasture growth, estimated from published data for lucerne and grass pastures in Otago, peaked in November while livestock demand peaked in January, our driest month. For 6 months of the year feed demand was higher than feed supply. Shifting feed into these months through making silage meant it was an expensive farm system.

An obvious opportunity for changing feed supply was irrigation. Realising irrigation development required an exit strategy, we considered dryland plants. The opportunity came from reading an article about Doug Avery (Avery et al. 2008) who had re-designed his drought-prone property using lucerne (Medicago sativa). This reinforced the simple point that lucerne was the most efficient pasture plant in converting spring soil moisture into pasture dry matter (Moot et al. 2008). It followed that in our 380-400 $\mathrm{mm}$ rainfall environment, where summer moisture is limiting, we should be maximising the use of this species.

Another pivotal experience was a study tour to South Africa where farmers were observed achieving 140\% lambing from merinos, which contrasted with the New Zealand experience of $80-100 \%$. Their systems emphasised the need to fully feed ewes throughout the year and prioritise light ewes from weaning to tupping. We started to consider how lucerne combined with a high ewe reproductive performance could help re-design our system to more closely balance feed supply and animal demand. We identified four key strategies to change;

- Maximise production of high quality feed for lactation. This involved replacing all grass pastures, 
including those irrigated, with lucerne. The productivity of lucerne in this environment was not fully quantified but a yield of $5.5 \mathrm{t}$ dry matter/ haannually was assumed.

- Increase feed demand during the height of the growing season. This involves fully feeding ewes from the start of lambing throughout lactation on the highest quality feed. Well fed ewes in good condition are less likely to mismother and this would decrease lamb mortality. Increases in lamb growth rate can also be expected and this would achieve a higher lamb weaning weight.

- Reduce feed demand in the driest month. This involved selling surplus lambs store in January, rather than trying to grow them in summer and then carrying them through winter as we had been. Achieving higher pre-weaning lamb growth rates to increase weights at weaning to achieve a higher store lamb price and sell all but replacement ewe lambs prior to the summer dry.

- Reduce demand during winter. Weaning heavier ewes reduced the need to put condition back on for tupping. This feed would be available for priority feeding of ewe hoggets to achieve a higher liveweight before the first winter. The gain would follow through to their first mating.

We set targets which, if achieved, would generate greater profit by increasing farm revenue, through greater sale numbers at heavier weights and decreasing the cost of winter feeding (Table 1). The productivity of lucerne in this environment was not clearly understood, but a yield of 5.5 tonnes of dry matter annually was assumed.

Table 1 The performance of the historic system, three year targets for the new lucerne based system set in 2010/2011 and the actual performance after 3 years as measured in 2013/14 at Bog Roy station.

\begin{tabular}{lccc}
\hline & $\begin{array}{c}\text { Historic } \\
\text { (Pre 2010) }\end{array}$ & $\begin{array}{c}\text { Year 3 } \\
\text { (target) }\end{array}$ & $\begin{array}{c}\text { Year 3 } \\
\text { (actual) }\end{array}$ \\
\hline Young stock & & & \\
Ewe lamb weight May (kg) & 35 & 37 & 38 \\
Two-tooth scanning (\%) & 111 & 115 & 129 \\
Two-tooth weaning (\%) & 84.0 & 92.0 & 100 \\
Two-tooth lamb mortality (\%) & 24 & 20 & 22 \\
Mixed age ewes & & & \\
Tupping weight (kg) & 57 & 60 & 59.5 \\
Ewe scanning (\%) & 165 & 165 & 165 \\
Ewe weaning (\%) & 115 & 125 & 130 \\
Ewe lamb mortality (\%) & 30 & 25 & 21 \\
Lamb weaning weight (kg) & 27 & 29 & 29 \\
Lamb growth rate (g/hd/day) & 205 & 235 & 235 \\
\hline
\end{tabular}

\section{Making the transition}

Bog Roy started the process by seeking assistance from Professor Derrick Moot. After the third year of making changes, the New Zealand Merino Company PGP commenced and it provided funding to expand the monitoring work that Lincoln University had initiated. This involved cutting pasture cages of lucerne on a monthly basis to generate data to compare the production from unimproved and improved pastures and to compare dryland lucerne with irrigated pastures and lucerne-grass mixes. The cut samples were sent to Lincoln University for oven drying and data analysis. At the same time the pre- and post-grazing heights of each lucerne paddock were recorded when stock were moved into and out of a paddock. At the end of the season these data were also sent to Lincoln University to analyse the amount of herbage produced and consumed from each paddock.

The initial transition started in a modular fashion with a block chosen that could be subdivided into six paddocks. This provided a system where a mob could be introduced at lambing and rotationally grazed until weaning. Doug Avery's experience highlighted the value of contour planting lucerne. This meant planting lucerne in paddocks that had a mix of valley basins that could be established into lucerne while leaving steeper or unfavourable areas undeveloped. These paddocks provide necessary stock shelter and ewes can be offered both high quality lucerne and grasses that balance their diet. Thus, the deeper soils are planted in lucerne and the shallower soils left with resident vegetation to provide other ecological services, such as shelter for new born lambs, increased biodiversity and visually appealing landscape farming.

Lucerne is established after two or more years in a fodder crop. During this period weeds can be targeted for control and any thatch of resident vegetation broken down through repeated hoof damage when break feeding the crop. The number of years in fodder crops will depend on how well these weeds have been eliminated. Ryecorn (Secale cereale) is used because it does not depend on rainfall during summer. Land is sprayed with a broad spectrum herbicide such as glyphosate in spring while there is still available soil moisture and this is conserved for planting in January. Weed control during this period with glyphosate provides the cheapest and most effective means of weed elimination for the lucerne stand. During this summer fallow any emerging weeds are sprayed, again to conserve moisture but also to eliminate resident vegetation. Ryecorn is an important component in the lucerne system because it provides feed in the winter months when lucerne is dormant from May to September. 


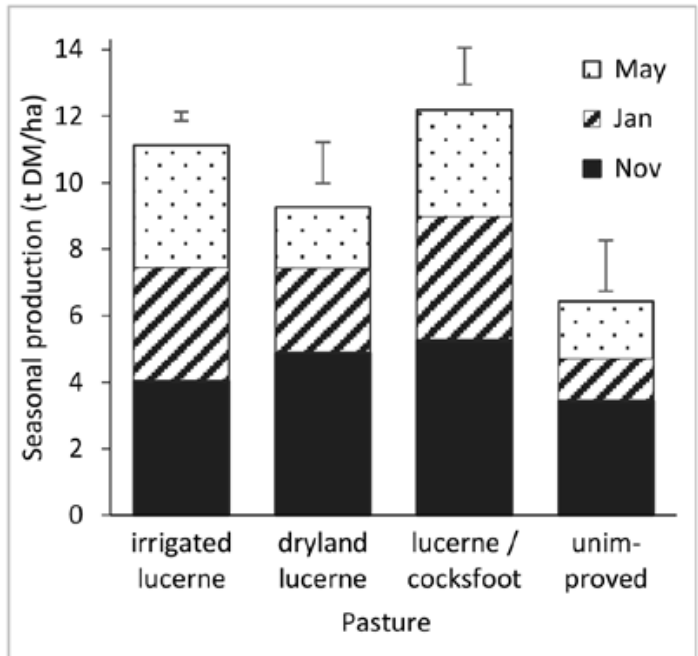

Figure 2 The annual average dry matter production measured from monthly cuts for the 2011/12, 2012/13 and 2013/14 seasons for irrigated lucerne, dryland lucerne, dryland lucerne and cocksfoot mix and from undeveloped native. The growth season is divided into three periods: August-November, Dec-January and Feb-May, respectively.

\section{Managing the lucerne system}

Lucerne is managed in the following phases. In the lactation phase ewes are scanned into singles and twins and foetal aged into early, mid and late lambers. Ewes carrying twins were the priority for lucerne, because with two lambs they have the greatest revenue potential. Foetal aging gives the ability to progressively set stock each lucerne block (for about 4 weeks at 7 ewes/ha) when it is ready; a minimum of $15-20 \mathrm{~cm}$ in height. At the end of lambing, ewes start a rotation with a maximum of 10 days in each paddock and a minimum of 30 days before returning. If the pre-graze height of a lucerne paddock gets above $45 \mathrm{~cm}$ it is dropped out of the rotation and either cut or grazed with another mob. Conversely, if it gets too short (less than $25 \mathrm{~cm}$ ) another paddock is added to the rotation to ensure we are not opening up the lucerne canopy which would allow perennial weeds like couch (Elymus repens), yarrow (Achillea millefolium) and dandelion (Taraxacum officinale) to establish during the set stocking period.

In the post-weaning phase in early January the aim is to allow lucerne 4 to 6 weeks to flower and replenish root reserves (Moot et al. 2003). Ewes are condition scored with those above 3 grazed on the hill while those below are grazed around the flowering lucerne. Our aim is to have all ewes at a condition score of 3 or higher by tupping. Through winter we maintain ewe condition score, particularly for twin-bearing ewes. From autumn ryecorn is fed, supplying most of our winter supplements through to late autumn-early winter. After

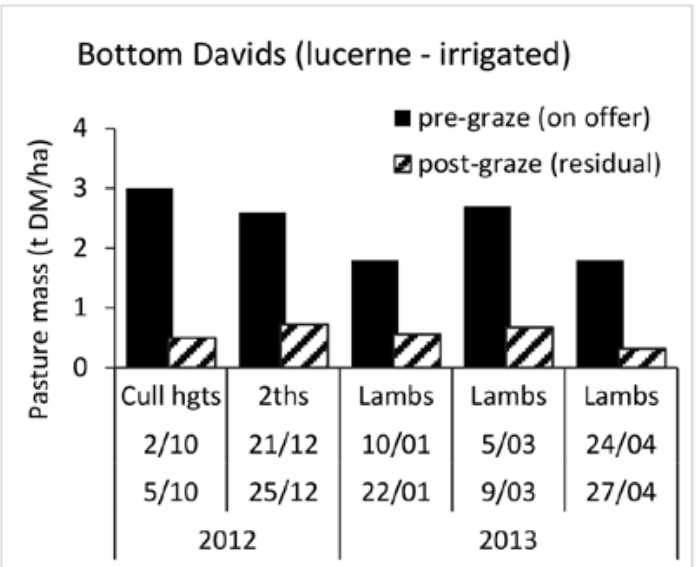

Wheatgrass (lucerne - dryland)

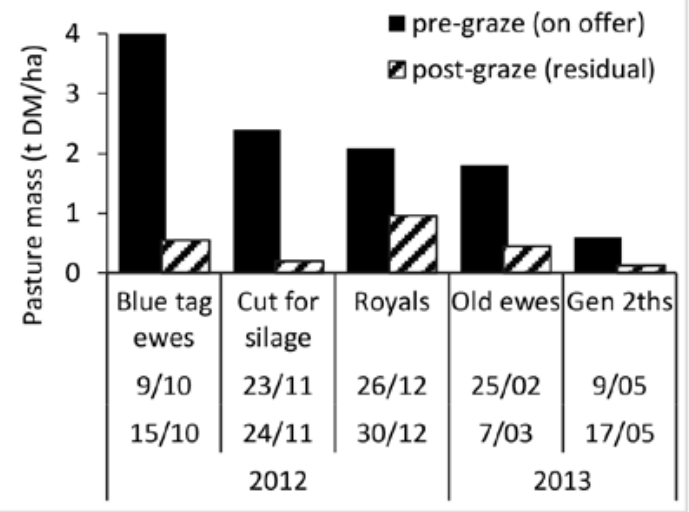

R G 2 (lucerne\&cocksfoot - dryland)

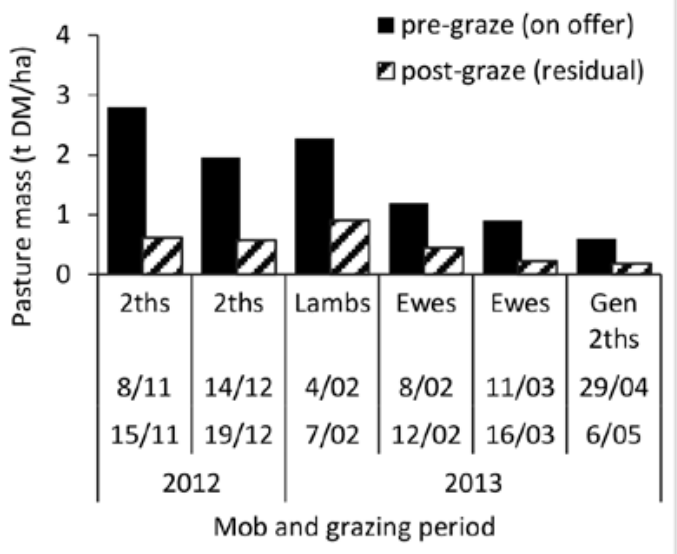

Figure 3 Pre- and post-grazing DM for three paddocks throughout the 2012-13 season detailing the mob shift history. 
this we use silage to fill the gap until ryecorn starts growing again in early August.

\section{Results and discussion}

The assistance we received was critical in giving us confidence to rapidly scale up the lucerne system. The pasture dry matter measurements showed how productive lucerne was (Figure 2). The dryland lucerne, irrigated lucerne and lucerne and cocksfoot produced 8.8, 10.5 and 11.5 tonnes of dry matter per hectare per year (t DM/ha/yr), respectively. This compared with $6 \mathrm{t}$ $\mathrm{DM} / \mathrm{ha} / \mathrm{yr}$ from oversown and topdressed areas (Figure 2).

As more blocks were developed the majority of twin ewes could be run on lucerne. With rotational grazing the recovery of paddocks can be seen more clearly, and the time of shift targeted for about $3.5 \mathrm{t} \mathrm{DM} / \mathrm{ha}$, or 40 $\mathrm{cm}$ height, on entry (Figure 3). This allows forward planning if recovery rates are faster or slower than expected. Fast recovery means more ewes and lambs can be introduced to the system. Equally, if spring rainfall or temperatures are below average the slower regrowth can be targeted to the mobs that most need it. This also gives an early warning if a feed deficit is developing due to dry conditions.

Another benefit has been that our native top dressed hill country areas have become progressively destocked during October. Over the past 3 years destocking these hill areas during the growing seasons has seen an estimated increase in legume content of $50 \%$. Initially, haresfoot trefoil (Trifolium arvense) covered the hills, but now there are a number of clovers including white clover (T. repens) and striated clover (T. striatum) with a noticeable reduction in H. pilosella. This has encouraged us to increase fencing and subdivision to establish an effective rotational grazing regime. With extra spring growth over a large area a buffer is created that can be used in summer to maintain ewes at a time when we traditionally had low covers and were in danger of overgrazing the hill areas.

Table 1 shows how livestock production in the 2013/14 season compares against our historical performance and the 3-year goal we targeted for this new system. Ewe hoggets are exceeding the new 1 May live weight target (38 kg versus $37 \mathrm{~kg}$, respectively). This has flowed through to two-tooth performance. Scanning has improved from $111 \%$ historically to $129 \%$, and weaning has improved from $84 \%$ to $100 \%$. This means lamb mortality (scanning to weaning) has reduced from $24 \%$ historically to $22 \%$. Mixed age ewes were already scanning well $(165 \%)$, and while this has not changed, lamb mortality has decreased from $30 \%$ to $21 \%$. We attribute this reduction to ewes being in improved condition and well-fed from the start of lambing. An important component in the new system

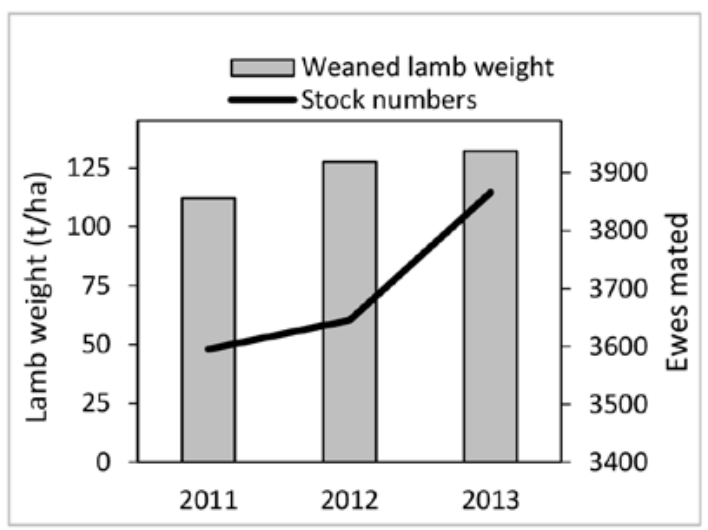

Figure 4 The number of mated ewes and the weight of lamb weaned for the 2011-12, 2012-13 and 2013/14 seasons.

has been achieving higher lamb growth rates (birth to weaning) during lactation which have increased from 205 to $235 \mathrm{~g} / \mathrm{hd} / \mathrm{d}$ averaged across all lambs. This means we are now weaning heavier lambs that are favourable for the store market. Figure 4 shows the total weight of weaned lamb has increase by $18 \%$ from an $8 \%$ increase in the number of mated ewes. Clean wool weights have been consistent at $3.4 \mathrm{~kg} / \mathrm{hd}$ for mixed aged ewes but increased from 2.0 to $2.6 \mathrm{~kg} / \mathrm{hd}$ for the hoggets. We expect the higher performance from young stock will increase adult stock performance in future.

The combination of selling surplus lambs as store, the ryecorn crops used for lucerne development and renewal, and the improvement in the feed wedge on our hill have reduced our feeding out period from 100 to 50 days. Supplements are no longer fed to cattle as there is normally sufficient feed left to clean up on the hill. In 2010 we spent $\$ 10.33 / \mathrm{SU}$ on supplementary feeding and this has reduced to $\$ 4.82 / \mathrm{SU}$ in 2013 .

\section{Conclusions}

In our dry environment lucerne provides the most efficient means of converting soil moisture into forage. The quality of lucerne enables high livestock growth rates in spring and early summer. This makes it possible for us to produce heavy lambs at weaning, which opens the opportunity for a store production system. We have shifted away from a system that produced light lambs that must be kept a further 10 months, 4 of these having negligible pasture growth. We have created a system that matches the biophysical components of our environment. This alignment has had other benefits. Feeding stock well has increased young ewe performance and reduced overall lamb losses, improving reproductive efficiency. It has also reduced our dependence on dry hill country during spring and summer. This has allowed a de-stocking period conducive to annual clovers and building cover 
for late autumn and early winter.

In the old system stock were spread across the hill and it was difficult to clearly understand how well ewes were being fed until the day of weaning. In contrast with the modular approach to integrating lucerne, mobs are allocated to blocks and rotationally grazed. Lucerne growth can be estimated from soil moisture and the number of days feeding ahead of ewes can be calculated. Together these changes provide an efficient system with hill country that is improving and one that we are more able to plan and control. The increase in lucerne area has decreased the pressure on the farm and, importantly, the farmers.

\section{ACKNOWLEDGEMENTS}

NZMerino Ltd through their primary growth partnership for financial support of data collection and analysis by Keith Pollock and the Lincoln University dryland pastures group. Doug Avery, Liam Donelly and Pete Anderson for valued support during the process of change.

\section{REFERENCES}

Avery, D.; Avery, F.; Ogle, G.I.; Wills, B.J.; Moot, D.J. 2008. Adapting farm systems to a drier future. Proceedings of the New Zealand Grassland Association 70: 13-18.

Marshall P.R.; McCall, D.G.; Johns, K.L. 1991. Stockpol: A decision support model for livestock farms. Proceedings of the New Zealand Grassland Association 53: 137-140.

Moot, D.J.; Brown, H.E.; Pollock, K.; Mills, A. 2008. Yield and water use of temperate pastures in summer dry environments. Proceedings of the New Zealand Grassland Association 70: 51-58.

Moot D.J.; Brown, H.E.; Teixeira, E.I.; Pollock, K.M. 2003. Crop growth and development affect seasonal priorities for lucerne management. In: Legumes for dryland pastures Ed. Moot, D.J. New Zealand Grassland Association, Research and Practice Series 11: 201-208.

Ogle, G.I. 2009. Integrated grower supply chain for production of merino lamb. Technical report prepared for Merino Inc. www.merinoinc.co.nz. 18 pp. 